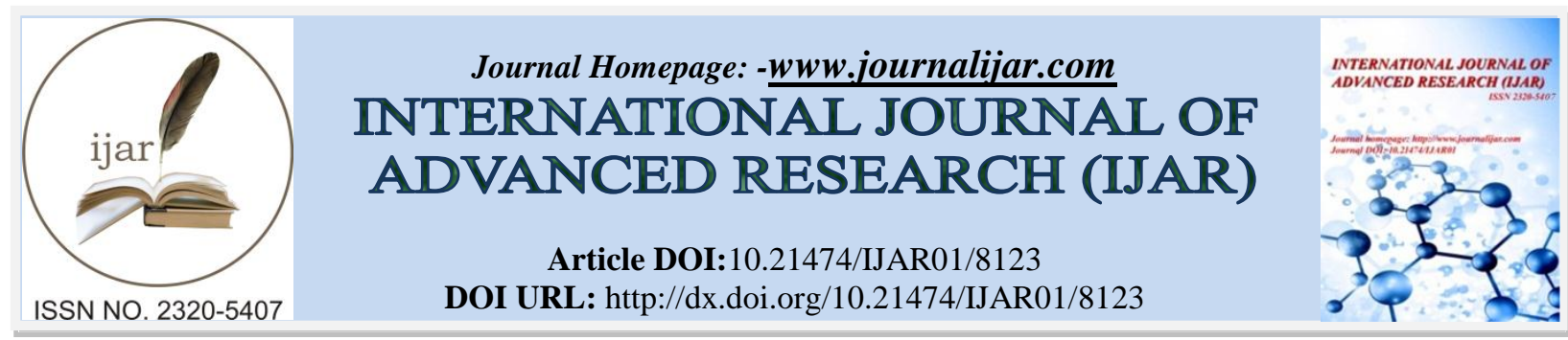

RESEARCH ARTICLE

\title{
STUDY ON BIOMETRIC INDEXES, PRODUCTIVITY AND QUALITY OF SOYBEAN WITH USAGE OF FERTILIZER PRODUCTS OF „AGROPOLYCHIM“ AD.
}

\author{
Dragomir Plamenov ${ }^{1}$, Pavlina Naskova ${ }^{1}$, Bojka Malcheva $^{2}$ and Yordan Iliev ${ }^{3}$. \\ 1. Department of Plant Production, Technical University - Varna, Varna, Bulgaria. \\ 2. Department of Soil Science, University of Forestry - Sofia, Sofia, Bulgaria. \\ 3. Department "Agrochemistry and Soil Science", "Afer Bulgaria" EOOD.
}

\section{Manuscript Info}

\section{Manuscript History}

Received: 01 October 2018

Final Accepted: 03 November 2018

Published: December 2018

Keywords:-

Biometric indexes, productivity, quality, soybean, fertilizer products.

\begin{abstract}
In the present experiment has been studied the impact of six fertilizer products of "Agropolychim“ AD over basic biometric indexes, the productivity and quality of soybean. For the purpose on a trainingexperimental field of "Plant production" department has been set an experiment with variety PR91M10. The results show that with largest height distinguishes the control, but the difference in comparison with the following it as per value three fertilizer variants is untrustworthy. There lacks proofness of the differences between the separate fertilizer products as per the indication number of beans on a plant (the value is highest with usage of ammonium nitrate), except for the fertilizing with UAN. The analysis of the data for number of seeds as per a plant indicates that the variant with DAP produces most, but the following it as per value three variants do not differ reliably from it. The seeds are best fed as a result of fertilizing with NPK and UAN. The data for productivity display statistically proved superiority with usage of MAP and DAP in comparison with the other products included in the experiment. The biochemical data display that with fertilizing with MAP is obtained a soybean with the highest content of protein and with lowest oiliness, and it is highest at the variant with UAN.
\end{abstract}

Copy Right, IJAR, 2018,. All rights reserved.

\section{Introduction:-}

Soybean has s high commercial value and high concentration of protein, about $40 \%$, calcium, phosphorus, fiber, and in addition it is cholesterol free (Hassan et al., 2010). It plays an important role in provision of food, cash and animal feeds (Mugendi et al., 2010). Soybean has potential to fix $\mathrm{N}$ from the atmosphere through biological fixation (Nieuwenhuis and Nieuwelink, 2002). Through research, it has been demonstrated that some varieties of this crop have the ability to fix nitrogen from 44 to $103 \mathrm{~kg} \mathrm{~N} \mathrm{ha}^{-1}$ annually (Sanginga, 2003). Although $\mathrm{N}$ fertilization of soybean is not a common practice there is speculation that the ability of soybean to fix atmospheric $\mathrm{N}$ is not always adequate for maximum yield (Weber, 1966; Wesley et al., 1998). There a number of factors influencing soybean $\mathrm{N}$ fixation and the response to applied N. Sorensen and Penas (1978) concluded that soil temperature, moisture, and pH affect soybean response to applied N. Starling et al. (1998), Afza et al. (1987) and Wood et al. (1993), reported that although soybean obtains $\mathrm{N}$ through symbiotic fixation, application of a $\mathrm{N}$ starter fertilizer has resulted in

Corresponding Author:-Dragomir Plamenov.

Address:-Department of Plant Production, Technical University - Varna, Varna, Bulgaria. 
increased vegetative growth and grain yield. Soybean yield showed a positive linear response to $\mathrm{P}$ and $\mathrm{K}$ fertilization (Casanova, 2000).

The purpose of the present development is to be studied the impact of various fertilizer products of „Agropolychim“ $\mathrm{AD}$ on basic biometric indexes, the yield and content of protein and oil of soybean.

\section{Material and Methods:-}

The experiment is carried out on a training-experimental field of "Plant production" department to Technical university - Varna. The experiment is set with variety soybean (Glycine max (L.) Merr.) PR91M10 (Pioneer Intl.) in two repetitions on 29 April 2015 with the following fertilizer products:

1. Ammonium Nitrate $\left(\mathrm{NH}_{4} \mathrm{NO}_{3}\right)-34.5 \% \mathrm{~N}$;

2. Monoammonium Phosphate (MAP) $-11 \% \mathrm{~N}, 52 \% \mathrm{P}_{2} \mathrm{O}_{5}$;

3. Diammonium Phosphate (DAP) $-18 \% \mathrm{~N}, 46 \% \mathrm{P}_{2} \mathrm{O}_{5}$;

4. Urea $\left(\mathrm{CO}\left(\mathrm{NH}_{2}\right)_{2}\right)-46 \% \mathrm{~N}$;

5. $\mathrm{NPK}-14 \% \mathrm{~N}: 14 \% \mathrm{P}_{2} \mathrm{O}_{5}: 14 \% \mathrm{~K}_{2} \mathrm{O}+11,5 \% \mathrm{~S}$;

6. Urea Ammonium Nitrate (UAN) $-32 \% \mathrm{~N}$.

Two control plots have been set for a greater objectivity of the study and comparability of the results.

The fertilizer products have been brought in before sowing, as the fertilizer norm is $70 \mathrm{~kg} / \mathrm{ha}$ nitrogen active substance for the soybean, recalculated for each of the repetitions.

Pioneer variety PR91M10 (maturity 1.0) soybean were seeded at a rate of 600000 seeds/ha. Soybean was inoculated with Bradyrhizobium japonicum before planting.

After finishing of the soybean vegetation is carried out gathering in phase complete ripeness (on 28 September 2015), as for each plant is carried out a biometrical analysis of the parameters: height of the plants, number of beans per plant, number of seeds per plant, as the normal and shriveled have been counted separately.

In conclusion, for each repetition of the six variants of the experiment is reported the productivity and qualitative indexes (content of protein and oiliness) with the assistance of NIR - analyzer (model DA7200 NIR, Perten Instruments).

The obtained biometrical data are statistically processed and the results are included in a dispersion analysis with calculation of the smallest proven difference between the variants with $\mathrm{p}=0.05\left(\mathrm{LSD}_{0.05}\right)$. There have also been determined the values of the coefficient of variation (CV). The statistical processing is carried out with the assistance of programme product STATISTICA, version 10 .

\section{Results and Discussion:-}

The meteorological conditions (minimum, average and maximum temperature) during the vegetation of soybean are displayed on Figure 1.

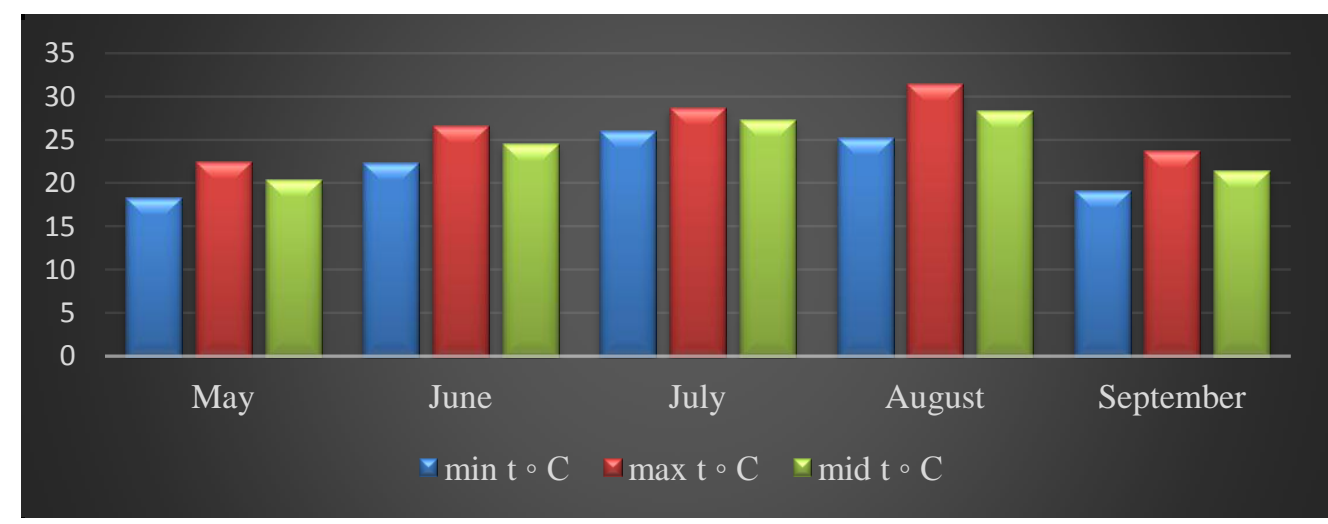

Fig.1:-Minimum, maximum and average value of the temperature for the experimental period 
The soybean begins its development at optimum conditions, as during month May is reported the lowest temperature of the air $\left(18.3^{\circ} \mathrm{C}\right)$. The maximum value is measured in month August $\left(31.5^{\circ} \mathrm{C}\right)$, when the average temperature also shows highest values $\left(28.4^{\circ} \mathrm{C}\right)$. Following the parameters of temperature during the phenological development of the soybean, it can be concluded that the conditions are favourable about the normal entering of the plants into the separate phenophases and termination of the vegetation. Regarding the average quantity of the precipitations is determined, that in the present study during month July is reported minimum quantity of the precipitations (9.6 $1 / \mathrm{m}^{2}$ ), which does not affect particularly favourably the soybean, which during this period enters in the reproductive phases, but at the expense of this the next month (August) differs with most precipitations $\left(62.4 \mathrm{l} / \mathrm{m}^{2}\right.$ ) (Plamenov et al., 2017).

In Table 1 are presented the results from the biometrical analysis of the indications height and number of beans of the plants in the experiment. With largest height of the stem are the plants from the control plots $(54.62 \mathrm{~cm})$, with which is reported and the smallest variation (18.36\%). There has not been determined a statistically proven difference of the values between the control and the variants MAP and NH4NO3, but in comparison with the other fertilizer variants (urea, DAP, NPK, UAN), is available. Most beans per plant are reported at usage of ammonium nitrate (29.06 numbers/plant), but their number is not reliably larger in comparison with the counted beans with the other fertilizer variants, except for UAN (with it are reported the smallest number of beans in the experiment -19.63 numbers/plant). With high values are also the plots, fertilized with MAP and DAP. The dispersion analysis finds a statistical trustworthiness by the indicator only between each of the six variants and UAN. The statistical analysis determines big variation between the reported number of beans per plant with all variants of the experiment (from 65.10 up to $91.49 \%)$.

Table 1:-Values of height of the plants and number of beans per plant of soybean

\begin{tabular}{|l|c|c|c|c|}
\hline Variants & \multicolumn{2}{|c|}{ Height of the plants, cm } & \multicolumn{2}{c|}{ Number of beans per plant } \\
\hline & Average & $\begin{array}{c}\text { Coefficient of } \\
\text { variation, \% }\end{array}$ & $\begin{array}{c}\text { Average } \\
\text { variation, \% }\end{array}$ \\
\hline Control & 54.62 & 18.36 & 25.29 & 77.42 \\
\hline $\mathrm{NH}_{4} \mathrm{NO}_{3}$ & 51.96 & 29.08 & 29.06 & 71.34 \\
\hline $\mathrm{CO}\left(\mathrm{NH}_{2}\right)_{2}$ & 48.61 & 28.66 & 25.38 & 88.57 \\
\hline $\mathrm{DAP}$ & 47.63 & 31.45 & 27.04 & 91.49 \\
\hline MAP & 53.30 & 27.34 & 28.74 & 82.19 \\
\hline $\mathrm{NPK}$ & 45.32 & 27.12 & 25.50 & 62.43 \\
\hline $\mathrm{UAN}$ & 46.26 & 21.34 & 19.63 & - \\
\hline $\mathrm{LSD}_{0.05}$ & 3.35 & - & 5.75 & \\
\hline
\end{tabular}

Largest number of seeds per plant are reported at usage of DAP (60.19), followed by the plots, fertilized with urea, MAP and NPK (with insignificantly differing values) (Table 2). The statistical analysis determines proofness of the difference at each of the four variants in comparison with the control and UAN. The high values of the variation coefficients make an impression, as smallest variation is available with the plots, fertilized with UAN. The obtained seeds differ in the degree of state of feeding, which imposed their grouping in two categories - normal and shriveled. It is determined, that the largest number of normal (fed) seeds are produced as a result of fertilizing with NPK (43.35 numbers/plant) and UAN (40.06 numbers/plant), as the difference as per the indicator in comparison with the other fertilizer variants is statistically reliable. Highest is the percentage share of normal seeds at usage of the liquid fertilizer product UAN (93.05\% out of all seeds), followed by the plots, fertilized with NPK (79.73\%). At the rest fertilizer products is reported a significant share of the shriveled seeds (from 41.25 up to $55.04 \%$ ).

Table 2:-Values of number of seeds per plant, normal and shriveled seeds

\begin{tabular}{|l|c|c|c|c|c|c|}
\hline \multirow{2}{*}{ Variants } & \multicolumn{2}{|c|}{ Number of seeds per plant } & \multicolumn{2}{c|}{ Normal seeds } & \multicolumn{2}{c|}{ Shriveled seeds } \\
\cline { 2 - 7 } & Average & $\begin{array}{c}\text { Coefficient of } \\
\text { variation, \% }\end{array}$ & Average & \% & Average & \% \\
\hline Control & 43.51 & 75.50 & 19.56 & 44.96 & 23.95 & 55.04 \\
\hline $\mathrm{NH}_{4} \mathrm{NO}_{3}$ & 49.83 & 74.73 & 25.84 & 51.86 & 23.99 & 48.14 \\
\hline $\mathrm{CO}\left(\mathrm{NH}_{2}\right)_{2}$ & 57.25 & 85.62 & 32.59 & 56.93 & 24.66 & 43.07 \\
\hline DAP & 60.19 & 95.96 & 35.36 & 58.75 & 24.83 & 41.25 \\
\hline
\end{tabular}




\begin{tabular}{|l|c|c|c|c|c|c|}
\hline MAP & 57.10 & 77.78 & 27.82 & 48.72 & 29.28 & 51.28 \\
\hline NPK & 54.37 & 96.27 & 43.35 & 79.73 & 11.02 & 20.27 \\
\hline UAN & 43.05 & 71.34 & 40.06 & 93.05 & 2.99 & 6.95 \\
\hline LSD $_{0.05}$ & 10.86 & - & 7.47 & - & 8.03 & - \\
\hline
\end{tabular}

In the present experiment highest yield demonstrate the variants with usage of MAP $(3067.3 \mathrm{~kg} / \mathrm{ha})$ and DAP $(2535.4 \mathrm{~kg} / \mathrm{ha}$ ), as the difference between them is not proven (Table 3). The statistical reliability is available between the two fertilizer products and the rest five variants of the experiment. In the studies of Casanova (2000) is determined also a proven difference with increasing of the content of phosphorus in the applied fertilizer product. There is available subordination between the yield with soybean and the phosphorus fertilizing, as usually the lack of a positive effect is connected with soils, which are characterized by high content of the macroelement (Borges and Mallarino, 2000; Wittry and Mallarino, 2004; Messiga et al., 2012). Gutierrez-Boem et al. (2007), Salvagiotti et al. $(2004,2012)$ report a reduction in the yield with this crop as a result of the low concentration of the nutritive element in the soil. Salvagiotti et al. (2013) determines, that the increase of the yield as result of phosphorus fertilizing is reported on areas, in which the content of phosphorus is not more than $12 \mathrm{mg} \mathrm{kg}-1$. It has to be marked, that in the present experiment the concentration of phosphorus in the soil is low (Plamenov et al., 2017), which explains the positive effect of the brought in phosphorus over the soybean productivity. Lowest yield in the experiment is reported with the control $(162.81 \mathrm{~kg} / \mathrm{ha})$, which displays, that the application of balanced mineral fertilizing even with a nitrogen fixing crop increases its productivity. With smallest variation as per plots are the yields with the control ( $\mathrm{VC}=7.86 \%)$, DAP $(7.91 \%)$ and MAP (15.52\%). Regarding the qualitative indexes is determined, that with fertilizing with MAP has been obtained bean with highest protein content (37.20\%), as the difference is statistically proven in comparison with three of the variants (control, DAP and NPK). The oiliness is highest of seeds as a result of usage of UAN (20.40\%), and the dispersion analysis displays, that there is available reliability in comparison with four of the variants (MAP, urea, ammonium nitrate and control). Consequently in the present experiment at usage of MAP is obtained soybean bean with highest content of protein and with lowest oiliness. In the studies of Ham et al. (1975) has been determined, that the pro-sowing bringing in of nitrogen increases the content of protein in the bean, but it does not have effect over the concentration of oil. This ascertainment has been confirmed in our study because of the fact, that the protein content is lowest in the unfertilized control, while as per oiliness the control occupies borderline position in comparison with the rest variants.

Table 3:-Productivity, content of protein and oil of soybean:-

\begin{tabular}{|l|c|c|c|c|c|c|}
\hline \multirow{2}{*}{ Variants } & \multicolumn{2}{|c|}{$\begin{array}{c}\text { Yield, } \\
\text { kg/ha }\end{array}$} & \multicolumn{2}{c|}{$\begin{array}{c}\text { Protein, } \\
\text { \% }\end{array}$} & \multicolumn{2}{c|}{$\begin{array}{c}\text { Oil, } \\
\text { \% }\end{array}$} \\
\cline { 2 - 7 } & Average & $\begin{array}{c}\text { Coefficient of } \\
\text { variation, \% }\end{array}$ & Average & $\begin{array}{c}\text { Coefficient of } \\
\text { variation, \% }\end{array}$ & Average & $\begin{array}{c}\text { Coefficient of } \\
\text { variation, \% }\end{array}$ \\
\hline Control & 1628.1 & 7.86 & 33.75 & 4.83 & 18.20 & 0.00 \\
\hline $\mathrm{NH}_{4} \mathrm{NO}_{3}$ & 2138.5 & 35.61 & 35.60 & 1.99 & 18.15 & 3.53 \\
\hline $\mathrm{CO}\left(\mathrm{NH}_{2}\right)_{2}$ & 2330.4 & 36.31 & 35.75 & 0.20 & 18.05 & 4.32 \\
\hline $\mathrm{DAP}$ & 2535.4 & 7.91 & 34.40 & 2.88 & 19.20 & 6.61 \\
\hline $\mathrm{MAP}$ & 3067.3 & 15.52 & 37.20 & 3.04 & 17.60 & 0.80 \\
\hline $\mathrm{NPK}$ & 1947.8 & 34.09 & 34.65 & 0.20 & 19.25 & 2.55 \\
\hline $\mathrm{UAN}$ & 2143.6 & 25.62 & 35.10 & 1.62 & 20.40 & 3.48 \\
\hline $\mathrm{LSD}_{0.05}$ & 736.9 & - & 2.55 & - & 1.65 & - \\
\hline
\end{tabular}

\section{Conclusion:-}

1. In the experimental study the control variant displays largest height of the plants in the experiment, but the differences in comparison with the variants with usage of urea, MAP and NPK are statistically unproven.

2. As per the indication number of beans per plant the highest value is reported with fertilizing with ammonium nitrate, but once again there lacks reliability of the differences in comparison with the other variants, except for UAN. At the usage of this fertilizing product has been obtained statistically proven the smallest number of beans per plant in the experiment. 
3. The largest number of beans per plant demonstrate the variants in the following decreasing order: DAP, urea, MAP and NPK, as the differences are not reliable. It has been determined, that the fertilizing with NPK and UAN is connected with the obtaining of larger number of normally fed soybean seeds.

4. The data about the productivity indicate, that the variants with usage of MAP and DAP statistically proven exceed as per yield the rest fertilizer products. The control unfertilized variant displays lowest productivity. The biochemical analysis reports, that with highest content of protein, but with lowest oiliness are the soybean seeds as a result of fertilizing with MAP, with presence of reliability in comparison with three of the variants (control, DAP and NPK). The oiliness is with highest values at usage of UAN, as the difference is proven in comparison with four of the variants (MAP, urea, ammonium nitrate and control).

\section{Acknowledgements:-}

The carried out research is realized in the frames of the project BG161PO003-1.2.04-0045-C0001/20.08.2013, Operational Program "Development of the Competitiveness of the Bulgarian Economy" 2007-2013.

\section{References:-}

1. Afza, R., Hardarson, G., Zapata, F. and Danso, S.K.A. 1987. Effects of delayed soil and foliar N fertilization on yield and $\mathrm{N}_{2}$ fixation of soybean. Plant Soil, 97: 361-368.

2. Borges, R. and Mallarino, A.P. 2000. Grain yield, early growth, and nutrient uptake of no-till soybean as affected by phosphorus and potassium placement. Agron. J., 92: 380-388.

3. Casanova, E., 2000. Phosphorus and potassium fertilization and mineral nutrition of soybean. Interciencia, 25(2): 92-95.

4. Gutierrez-Boem, F.H., Prystupa, P., Ferraris, G. 2007. Seed number and yield determination in sulfur deficient soybean crops. J. Plant Nutr., 30: 93-104.

5. Hassan, A., Mohamad, A., Abdu, A., Idrus, R.M. and Besar, N.A. 2010. Soil properties under Orthosiphon stamineus (Benth) intercropped with Durio zibethinus (Murr) and treated with various organic fertilizers. Paper presented on $19^{\text {th }}$ World Congress of Soil Science, Soil Solutions for a Changing World 1-6 August 2010, Brisbane, Australia.

6. Messiga, A.J., Ziadi, N., Morel, C., Grant, C., Tremblay, G., Lamarre, G. and Parent, L-E. 2012. Long term impact of tillage practices and biennial $\mathrm{P}$ and $\mathrm{N}$ fertilization on maize and soybean yields and soil $\mathrm{P}$ status. Field Crops Research 133: 10-22.

7. Mugendi, E., Gitonga, N., Oheruiyot, R. and Maingi, J. 2010. Biological nitrogen fixation by promiscuous soybean (Glycine $\max$ L. Merril) in the central highlands of Kenya: response to inorganic fertilizer soil amendments. World J. Agric. Sci., 6(4): 381-387.

8. Nieuwenhuis, R. and Nieuwelink, J. 2002. Cultivation of soybean and other legumes. Agrodok-Series No. 10. Agromisa Foundation, Wageningen, The Netherland.

9. Plamenov, D., Naskova, P. and Yankova, P. 2017. Study of the macronutrient elements content in the soil at a fertilizer experiment with soybean (Glycine max (L.) Merr.). International Journal of Horticulture, Agriculture and Food Science, 1(4): 17-23.

10. Salvagiotti, F., Gerster, G., Bacigaluppo, S., Castellarín, J.M., Galarza, C., González, N., Gudelj, O., Novello, O.A., Pedrol, H.M. and Vallone, P. 2004. Efectos residualez y directos de fósforo y azufre en el rendimiento de soja de segunda. Cienc. Suelo, 22: 92-101.

11. Salvagiotti, F., Ferraris, G., Quiroga, A., Barraco, M., Vivas, H., Prystupa, P., Echeveria, H.E. and GutierrezBoem, F.H. 2012. Identifying sulfur deficient fields by using sulfur content: $N: S$ ratio and nutrient stoichiometric relationships in soybean seeds. Field Crops Res., 135: 107-115.

12. Salvagiotti, F., Barraco, M., Dignani, D., Sanchez, H., Bono, A., Vallone, P., Gerster, G., Galarza, C., Montoya, J. and Gudelj, V.J. 2013. Plant stand, nodulation and seed yield in soybean as affected by phosphate fertilizer placement, source and application method. Europ. J. Agronomy 51: 25-33.

13. Sanginga, N. 2003. Role of biological nitrogen fixation in legume based cropping systems: a case study of West Africa farming systems. Plant and Soil, 252: 25-39.

14. Sorensen, R.C. and Penas, E.J. 1978. Nitrogen fertilization of soybeans. Agron. J., 79: 986-991.

15. Starling, M.E., Wesley, C., Wood, C.W. and Weaver, D.B. 1998. Starter nitrogen and growth habit effects on late-planted soybean. Agronomy Journal, 90(5): 658-662.

16. Weber, C.R.1966. Nodulating and nonnodulating soybean isolines: II. Response to applied nitrogen and modified soil conditions. Agron. J., 58: 46-49. 
17. Wesley, T.L., Lamond, R.E., Martin, V.L. and Duncan, S.R. 1998. Effects of late-season nitrogen fertilizer on irrigated soybean yield and composition. J. Prod. Agric., 11: 331-336.

18. Wittry, D.J., Mallarino, A.P. 2004. Comparison of uniform- and variable-rate phosphorus fertilization for cornsoybean rotations. Agron. J., 96: 26-33.

19. Wood, C.W., Torbet, H.A. and Weaver, D.B. 1993. Nitrogen fertilizer effects on soybean growth, yield, and seed composition. J. Prod. Agric., 6: 354-360. 